\title{
How freckles correlate with normal body temperature?
}

\author{
Aqsa Asghar* and Muhammad Imran Qadir \\ Institute of Molecular Biology and Biotechnology, Pakistan \\ *Corresponding author: Aqsa Asghar, Institute of Molecular Biology and Biotechnology, Multan, Pakistan
}

\begin{tabular}{|c|c|}
\hline ARTICLE INFO & ABSTRACT \\
\hline Received: 蔧 February 12, 2019 & The aim of the present study was to find the link between normal body temperature \\
\hline Published: February 25, 2019 & $\begin{array}{l}\text { or freckles. The thing that keeps the temperature maintains called a temperature control } \\
\text { system. We check the normal body temperature that is higher during the fever. Tempera- }\end{array}$ \\
\hline
\end{tabular}
normal body temperature?. Biomed J Sci \& Tech Res 15(1)-2019. BJSTR. MS.ID.002657.

Keywords: Dark spot temperature melanin

\section{Introduction}

Normal body temperature also called normothermia or euthermia. the thing that keeps the organisms at optimum operating temperature is called the temperature control mechanism. The rate of chemical reaction that affects the homeostatic mechanism [1]. By the time of the day, normal temperature varies from person to person. a range of normal temperature is the measurement of normal temperature. The 37 is the range of normal body temperature. The temperature changes in a day many times like a healthy person have o.5. a person is hungry sleepy sick or cold his temperature changes every moment of his body [2]. Normal temperature is sensitive to many hormones. Temperature also varies with the change of season during each year. This is called a circannual rhythm. everyone has a different normal body temperature. For an adult, normal body temperature can be 97.99 [3]. When the temperature of the body is higher this is also called fever. For children, fever is more complicated. Between 3 months or 3 years and has a rectal temperature over 102. Your temperature based on where your body you measure it. Freckles are small brown spots on the skin. overproduction of melanin causes the freckle which is responsible for hair colour and skin [4]. There are two types of a freckle. Epihalides or lengths. Epihalide is most common in the skins of people. But lignite's in the more production of melanin during pregnancy causes a dark spot on the skin. This includes agin sunspot or freckles [5].

\section{Material and Method}

We check the body temperature by a different method. We also check by the different method like a thermometer. The thermometer also has different types like automated or by mercury. First, we take a thermometer or check their normal body temperature. 98 is the normal temperature. put the thermometer into your mouth below the tongue. If you have a fever it shows on the thermometer. note that reading [6].

\section{Project Design}

We check the normal body temperature of the body. And last we noted their temperature. All the student was related to our university.

\section{Statistical and Analysis}

we use MS Excel software to find the statistical analysis of normal body temperature. $\mathrm{P}<0.1$ is a significant value.

\section{Result and Discussion}

A relationship between freckles and normal body temperature (Table 1). The result is significant. They introduce that there is a strong relationship between body temperature and freckles $[7,8]$.

Table 1.

\begin{tabular}{|c|c|c|c|}
\hline GENDER & $\begin{array}{c}\text { HAVING } \\
\text { FRECKLES }\end{array}$ & $\begin{array}{c}\text { NOT HAVING } \\
\text { FRECKLES }\end{array}$ & P-VALUE \\
\hline MALE & $97.48 \pm 1.98$ & $0.51 \pm 0.05$ & 0.5 \\
\hline FEMALE & $96.3 \pm 2.02$ & $96.14 \pm 4.8$ & 0.6 \\
\hline COMBINED & $96.8 \pm 2.03$ & $96.46 \pm 4.5$ & 0.8 \\
\hline
\end{tabular}

\section{Conclusion}

We concluded this discussion in these words that there is a strong connection between freckles and normal body temperature 
when we talk about the overall population.

\section{References}

1. Qadir MI, Javid A (2018) Awareness about Crohn's Disease in biotechnology students. Glo Adv Res J Med Medical Sci 7(3): 062-064.

2. Qadir MI, Saleem A (2018) Awareness about ischemic heart disease in university biotechnology students. Glo Adv Res J Med Medical Sci 7(3) 059-061.

3. Qadir MI, Ishfaq S (2018) Awareness about hypertension in biology students. Int J Mod Pharma Res 7(2): 08-10.

4. Qadir MI, Mehwish (2018) Awareness about psoriasis disease. Int J Mod Pharma Res 7(2): 17-18.

\section{ISSN: 2574-1241}

DOI: 10.26717/BJSTR.2019.15.002657

Aqsa Asghar. Biomed J Sci \& Tech Res

(C) This work is licensed under Creative

Submission Link: https://biomedres.us/submit-manuscript.php
5. Qadir MI, Shahzad R (2018) Awareness about obesity in postgraduate students of biotechnology. Int J Mod Pharma Res, 7(2): 14-16.

6. Qadir MI, Rizvi M (2018) Awareness about thalassemia in post graduate students. MOJ Lymphology \& Phlebology 2(1): 14-16.

7. Qadir MI, Ghalia BA (2018) Awareness survey about colorectal cancer in students of M. Phil Biotechnology at Bahauddin Zakariya University, Multan, Pakistan. Nov Appro in Can Study 1(3).

8. Qadir MI, Saba G (2018) Awareness about intestinal cancer in university student. Nov Appro in Can Study 1(3).

$\begin{array}{ll}\text { BIOMEDICAL } & \text { Assets of Publishing with us } \\ \text { RESEARCHES } & \text { - Global archiving of articles } \\ & \text { - Immediate, unrestricted online access } \\ & \text { - Rigorous Peer Review Process } \\ \end{array}$

